\title{
The static demand multipliers in a joint production framework: comparative findings for the Greek, Spanish and Eurozone economies
}

\author{
Theodore Mariolis $^{{ }^{*} \mathbb{D} \text {, Nikolaos Ntemiroglou }{ }^{1} \text { and George Soklis }}{ }^{2}$
}

*Correspondence:
mariolis@hotmail.gr
${ }^{1}$ Department of Public
Administration, Panteion
University, Athens, Greece
Full list of author information
is available at the end of the
article

*Correspondence: mariolis@hotmail.gr Administration Panteion University, Athens, Greece

\begin{abstract}
This paper uses input-output data from Supply and Use Tables for the year 2010 and provides empirical estimations of the static demand multipliers in a joint production framework for two representative Southern Eurozone economies, i.e., Greece and Spain, and for the Eurozone economy as a whole. The findings reveal certain differentiated features of the economies under consideration, call into question the post-2010 'horizontal' implementation of economic policy measures and, finally, provide a context for formulating well-targeted effective demand management and structural policy programs.
\end{abstract}

Keywords: Joint production, Management of effective demand, Matrix multipliers, Southern Eurozone economies, Supply and Use Tables

JEL Classification: C67, D57, E11, E12, E61

\section{Introduction}

The recession of the years 2008-2009 revealed the fiscal and external imbalances of the so-called Southern Eurozone economies and resulted in incapability of debt refinancing and increasing instability of the banking system. The reform agendas adopted since 2010, basically a mix of contractionary fiscal policy and internal devaluation, seem to have deepened the impact of recession on GDP and unemployment. Regarding the Eurozone (EZ) as a whole, it has been estimated that, between 2011 and 2104, the followed fiscal consolidation actions "came at a considerable cost with an output loss of $7.7 \%$ and only a small gain to the primary balance of $0.2 \%$ of GDP" (Gechert et al. 2016). These facts and figures probably suggest that the magnitudes of the demand multipliers should be carefully taken into consideration before the implementation of any policy measures.

As is now well known, the multiplier for an actual economy does not constitute a scalar but a vector quantity and, therefore, relevant empirical estimations have to zero in on the existing interindustry linkages. Pouring "(some) water into the wine of traditional macroeconomics", Kurz (1985) introduced and explored the concept of matrix multiplier of autonomous demand in Sraffa's (1960, Part I) closed-economy framework. Thus, he demonstrated that: "[T]here is no such thing as 'the' multiplier. Rather the multiplier effects depend on the technical conditions of production, income distribution,

(c) The Author(s) 2018. This article is distributed under the terms of the Creative Commons Attribution 4.0 International License (http://creativecommons.org/licenses/by/4.0/), which permits unrestricted use, distribution, and reproduction in any medium, provided you give appropriate credit to the original author(s) and the source, provide a link to the Creative Commons license, and indicate if changes were made. 
consumption patterns and the physical composition of investment, as well as on savings ratios and the aggregate volume of investment." (pp. 134-135). It could, furthermore, be shown that this static matrix multiplier includes, as special versions or limit cases, the usual Keynesian multipliers, the multipliers of the traditional input-output analysis and their Marxian versions. ${ }^{1}$ Furthermore, combining the contributions of Malinvaud (1959) and Morishima (1960) with that of Metcalfe and Steedman (1981), Mariolis (2008) extended the static matrix multiplier to the case of an open, linear system involving only circulating capital and producing $n$ commodities by $n$ processes (or industries) of pure joint production ('square' system).

The present paper provides empirical estimations and policy-oriented analysis of the output, import and employment matrix multipliers for two representative Southern EZ economies, i.e., Greece and Spain, and for the EZ economy as a whole. For this purpose, we use:

1. Input-output data from the Supply and Use Tables (SUTs) for the 'pre-adjustment' year of $2010 .^{2}$ Since joint production is the empirically relevant case, and since the SUTs may be considered as the empirical counterpart of joint production systems, it follows that these tables constitute a more realistic representation of actual economies than Symmetric Input-Output Tables. ${ }^{3}$

2. The analytic framework of Mariolis and Soklis (2018), i.e., a square joint production model of heterogeneous labor involving only circulating capital and competitive imports. The particular structure of this model is imposed by the available SUTs, which provide no data on fixed capital stocks and non-competitive imports. For the case of the Greek economy, they also provide no data on imported intermediate inputs.

The remainder of the paper is structured as follows. Section 2 outlines, in brief, the analytic framework. ${ }^{4}$ Section 3 presents and evaluates the main empirical results. Finally, Sect. 4 concludes.

\section{Method}

Consider an open, linear system involving only circulating capital and producing $n$ commodities by $n$ industries of pure joint production. Furthermore, assume that (1) the input-output coefficients are fixed; (2) there are no non-competitive imports; (3) the net product is distributed to profits and wages that are paid at the end of the common production period; (4) the price of a commodity obtained as an output at the end of the production period is the same as the price of that commodity used as an input at the beginning of that period ('stationary prices'); and (5) each process uses only one type of labor.

\footnotetext{
${ }^{1}$ See Kurz (1985, pp. 126-127), Mariolis (2018a), Mariolis and Soklis (2018) and the references therein.

2 At the time of this research (September 2016), SUTs were available for the following years: 2005 through 2012 for the Greek economy; 2008 through 2010 for the Spanish economy; and 2008 through 2011 for the EZ economy.

3 See, e.g., Kurz (2006), Mariolis and Soklis (2010) and the references therein.

${ }^{4}$ For detailed explorations, see Mariolis (2018a) and Mariolis and Soklis (2018).
} 
On the basis of these assumptions, the price side of the system is described by ${ }^{5}$

$$
\mathbf{p}^{\mathrm{T}} \mathbf{B}=\mathbf{w}^{\mathrm{T}} \hat{\mathbf{l}}+\mathbf{p}^{\mathrm{T}} \mathbf{A}[\mathbf{I}+\hat{\mathbf{r}}]
$$

where $\mathbf{B}(\geq \mathbf{0})$ denotes the $n \times n$ output coefficients matrix, $\mathbf{A}(\geq \mathbf{0})$ the $n \times n$ input coefficients matrix, I the $n \times n$ identity matrix, $\hat{\mathbf{1}}\left(l_{j}>0\right)$ the $n \times n$ matrix of direct labor coefficients, $\mathbf{p}^{\mathrm{T}}\left(>\mathbf{0}^{\mathrm{T}}\right)$ the $1 \times n$ vector of commodity prices, $\mathbf{w}^{\mathrm{T}}\left(w_{j}>0\right)$ the $1 \times n$ vector of money wage rates, and $\hat{\mathbf{r}}\left(r_{j} \geq-1\right.$ and $\left.\hat{\mathbf{r}} \neq \mathbf{0}\right)$ the $n \times n$ matrix of the exogenously given and constant sectoral profit rates.

Provided that $[\mathbf{B}-\mathbf{A}]$ is non-singular, Eq. (1) can be rewritten as

$$
\mathbf{p}^{\mathrm{T}}=\mathbf{w}^{\mathrm{T}} \boldsymbol{\Lambda}+\mathbf{p}^{\mathrm{T}} \mathbf{H}
$$

where $\mathbf{H} \equiv \mathbf{A} \hat{\mathbf{r}}[\mathbf{B}-\mathbf{A}]^{-1}$ may be considered as the $\hat{\mathbf{r}}$ - vertically integrated technical coefficients matrix', and $\boldsymbol{\Lambda} \equiv \hat{\mathbf{l}}[\mathbf{B}-\mathbf{A}]^{-1}$ denotes the matrix of direct and indirect labor requirements per unit of net output for each commodity. ${ }^{6}$

The quantity side of the system is described by

$$
\mathbf{B x}=\mathbf{A x}+\mathbf{y}
$$

or

$$
\mathbf{x}=[\mathbf{B}-\mathbf{A}]^{-1} \mathbf{y}
$$

and

$$
\mathbf{y}=\mathbf{c}_{w}+\mathbf{c}_{p}-\mathbf{I m}+\mathbf{d}
$$

or, setting $\mathbf{I m}=\hat{\mathbf{m}} \mathbf{B x}$,

$$
\mathbf{y}=\mathbf{c}_{w}+\mathbf{c}_{p}-\hat{\mathbf{m}} \mathbf{B x}+\mathbf{d}
$$

where $\mathbf{x}$ denotes the $n \times 1$ activity level vector, $\mathbf{y}$ the vector of effective final demand, $\mathbf{c}_{w}$ the vector of consumption demand out of wages, $\mathbf{c}_{p}$ the vector of consumption demand out of profits, Im the import demand vector, $\mathbf{d}(\geq \mathbf{0})$ the autonomous demand vector (government expenditures, investments and exports), and $\hat{\mathbf{m}}$ the matrix of imports per unit of gross output of each commodity.

If $\mathbf{f}(\geq \mathbf{0})$ denotes the exogenously given, uniform and constant consumption pattern (associated with the two types of income), and $s_{w}\left(s_{p}\right)$ denotes the savings ratio out of wages (out of profits), where $0 \leq s_{w}<s_{p} \leq 1$, then Eqs. (2) and (3) imply that the consumption demands amount to

$$
\begin{aligned}
& \mathbf{c}_{w}=\left[\left(1-s_{w}\right)\left(\mathbf{w}^{\mathrm{T}} \boldsymbol{\Lambda} \mathbf{y}\right)\left(\mathbf{p}^{\mathrm{T}} \mathbf{f}\right)^{-1}\right] \mathbf{f} \\
& \mathbf{c}_{p}=\left[\left(1-s_{p}\right)\left(\mathbf{p}^{\mathrm{T}} \mathbf{H y}\right)\left(\mathbf{p}^{\mathrm{T}} \mathbf{f}\right)^{-1}\right] \mathbf{f}
\end{aligned}
$$

\footnotetext{
${ }^{5}$ Matrices (and vectors) are delineated in boldface letters. The transpose of an $n \times 1$ vector $\mathbf{x} \equiv\left[x_{i}\right]$ is denoted by $\mathbf{x}^{\top}$ and the diagonal matrix formed from the elements of $\mathbf{x}$ is denoted by $\hat{\mathbf{x}}$. Finally, e denotes the summation vector, i.e. $\mathbf{e} \equiv[1,1, \ldots, 1]^{\top}$, and $\mathbf{e}_{i}$ the $i$ th unit vector.

${ }^{6}$ As is well known, both $\mathbf{H}$ and $\boldsymbol{\Lambda}$ are not necessarily semi-positive matrices (consider, e.g., Kurz and Salvadori 1995 , ch. 8). When $[\mathbf{B}-\mathbf{A}]^{-1}$ is (semi-) positive, the system retains all the essential properties of single-product systems (Schefold 1978).
} 
where the terms in brackets represent the levels of consumption demands out of wages and profits, respectively.

Substituting Eqs. (5) and (6) into Eq. (4) finally yields

$$
\mathbf{y}=[\mathbf{C}-\mathbf{M}] \mathbf{y}+\mathbf{d}
$$

where

$$
\mathbf{C} \equiv\left(\mathbf{p}^{\mathrm{T}} \mathbf{f}\right)^{-1} \mathbf{f}\left[\left(1-s_{w}\right) \mathbf{w}^{\mathrm{T}} \boldsymbol{\Lambda}+\left(1-s_{p}\right) \mathbf{p}^{\mathrm{T}} \mathbf{H}\right]
$$

is the matrix of total consumption demand, and

$$
\mathbf{M} \equiv \hat{\mathbf{m}} \mathbf{B}[\mathbf{B}-\mathbf{A}]^{-1}
$$

is the matrix of total import demand.

Provided that $[\mathbf{I}-\mathbf{C}+\mathbf{M}]$ is non-singular (consider Mariolis 2008, pp. 660-661 and 663), Eq. (7) can be uniquely solved for $\mathbf{y :}$

$$
y=\Pi d
$$

where $\boldsymbol{\Pi} \equiv[\mathbf{I}-\mathbf{C}+\mathbf{M}]^{-1}$ is the static multiplier linking autonomous demand to net output, i.e., a matrix multiplier in a Sraffian joint production and open economy framework. It is a multiplier of commodities (instead of industries) and the multiplier effects depend, in a rather complicated way, on the: (1) technical conditions of production; (2) imports per unit of gross output; (3) distributive variables $\left(w_{j}^{-1} \mathbf{w}\right.$ and $\left.\hat{\mathbf{r}}\right) ;(4)$ savings ratios out of wages and profits; (5) consumption pattern; and (6) physical composition of autonomous demand. ${ }^{7}$ It goes without saying that, in general, any change in relative commodity prices, induced, directly or indirectly, by changes in income distribution, alters the elements of this matrix multiplier and, therefore, the total multiplier effects become ambiguous. This ambiguity is a distinctive feature of the multiplier process in Sraffian frameworks (Metcalfe and Steedman 1981; Mariolis 2008).

Finally, Eqs. (3) and (8) imply that the volumes of employment, $\mathbf{L} \equiv \hat{\mathbf{l}} \mathbf{x}$, associated with d are given by

$$
\mathbf{L}=\Lambda \Pi d
$$

Thus, the employment effects of $\mathbf{d}$ can be decomposed (Kahn 1931) into 'primary employment' effects, i.e.,

$$
\mathbf{L}_{\mathrm{I}} \equiv \Lambda \mathbf{d}
$$

and 'secondary employment' effects, i.e.,

$$
\mathbf{L}_{\mathrm{II}} \equiv \mathbf{L}-\mathbf{L}_{\mathrm{I}}=\boldsymbol{\Lambda}[\boldsymbol{\Pi}-\mathbf{I}] \mathbf{d}
$$

From Eqs. (8) and (9), it then follows that the changes on (1) the money value of net output, $\Delta_{y}^{i}$ (output multiplier); (2) the money value of imports, $\Delta_{I m}^{i}$ (import multiplier);

\footnotetext{
${ }^{7}$ In the (more realistic) case of direct taxation, the term $\left(1-s_{q}\right), q=w, p$, should be replaced by $\left(1-s_{q}\right)\left(1-t_{q}\right)$, where $t_{q}$ denotes the tax rate; see Mariolis (2018a), paper that extends the analysis to the case of indirect taxation and changes in income distribution-technical production conditions. It also shows that the matrix multiplier in Sraffian frameworks involves an autonomous demand-transfer payments iso-employment frontier, which exhibits formal similarities with the well-known dual consumption-growth and wage-profit relationships in steady-state capital and growth theory.
} 
and (3) total employment, $\Delta_{L}^{i}$ (total employment multiplier), induced by the increase of 1 unit of the autonomous demand for commodity $i$, are given by

$$
\begin{aligned}
& \Delta_{y}^{i} \equiv \mathbf{p}^{\mathrm{T}} \Pi \mathbf{e}_{i} \\
& \Delta_{I m}^{i} \equiv \mathbf{p}^{\mathrm{T}} \mathbf{M} \Pi \mathbf{e}_{i}
\end{aligned}
$$

and

$$
\Delta_{L}^{i} \equiv \mathbf{e}^{\mathrm{T}} \boldsymbol{\Lambda} \Pi \mathbf{e}_{i}
$$

respectively.

\section{Results and discussion}

The application of our analytic framework to the SUTs of the Greek (GR), Spanish (SP) and EZ economies for the year $2010(n=63)$ gives the following main results ${ }^{8}$ :

1. The matrices $[\mathbf{B}-\mathbf{A}]^{-1}$ exist and contain negative elements. (Nevertheless, their diagonal elements are all positive.) Consequently, the actual economies under consideration do not have the properties of single-product systems.

2. Table 1 reports the estimations for the output, $\Delta_{y}^{i}$, and import, $\Delta_{I m}^{i}$, multipliers [see Eqs. (10) and (11)] for the case where $s_{w}=0$ and $s_{p}=1$. $^{9}$ The last two columns give the percentage deviations of the EZ multipliers from those of the Greek and Spanish economies, and the last row gives the arithmetic mean of the multipliers for the total economy (TE). Finally, it is noted that the diagonal elements of the matrices $\boldsymbol{\Pi}$ and МП are all positive.

3. Table 2 reports the estimations for the total employment multipliers, $\Delta_{L}^{i}$ [see Eq. (12)], the primary employment multipliers, $\Delta_{L I}^{i} \equiv \mathbf{e}^{\mathrm{T}} \boldsymbol{\Lambda} \mathbf{e}_{i}$, and the secondary employment multipliers, $\Delta_{L I I}^{i} \equiv \mathbf{e}^{\mathrm{T}} \boldsymbol{\Lambda}[\boldsymbol{\Pi}-\mathbf{I}] \mathbf{e}_{i}$, as percentages of the total employment multipliers, i.e., $\Delta_{L I I}^{i}\left(\Delta_{L}^{i}\right)^{-1}$ [see Eq. $\left.(9 \mathrm{a}, \mathrm{b})\right]$. The last column gives the percentage deviations of the EZ total employment multipliers from those of the Greek and Spanish economies, and the last row gives the arithmetic means for the total economy. Finally, it is noted that the diagonal elements of the matrices $\boldsymbol{\Lambda} \boldsymbol{\Pi}$ are all positive.

From these results it is deduced that:

1. In terms of all multipliers, the EZ economy is more correlated with the Spanish economy rather than with the Greek one. More specifically, Table 3 gives the correlation matrix between the economies' output, import and total employment multipliers. It

\footnotetext{
${ }^{8}$ For the available input-output data as well as the construction of the relevant variables, see the Appendix 1 . The analytical results are available on request from the authors.

9 All the numerical results reported hereafter correspond to this case. Nevertheless, the graphs in Appendix 2 display the arithmetic means of the output multipliers, $\bar{\Delta}_{y}^{i}$, as functions of the savings ratios for (a) $s_{W}=0$ and $0 \leq s_{p} \leq 1$; and (b) $0 \leq s_{W} \leq 1$ and $s_{p}=1$. We consider that this parametric analysis also captures the case of direct taxation (see footnote 7). Typical findings in many empirical studies suggest that $s_{W}<s_{p}$ and the difference between $s_{w}$ and $s_{p}$ is significant (say, in the range of 30-50\%; see, e.g., Hein and Schoder 2011; Onaran and Galanis 2012, and the references therein). Thus, we presume that the results for the (polar) case $s_{w}=0$ and $s_{p}=1$ are sufficiently representative.
} 
Table 1 Output and import multipliers and their percentage deviations

\begin{tabular}{|c|c|c|c|c|c|c|c|c|c|c|}
\hline \multirow[t]{2}{*}{$i$} & \multicolumn{2}{|l|}{ GR } & \multicolumn{2}{|l|}{ SP } & \multicolumn{2}{|l|}{$E Z$} & \multicolumn{2}{|c|}{$\begin{array}{l}\text { Percentage deviations } \\
\Delta_{y}^{i}\end{array}$} & \multicolumn{2}{|c|}{$\begin{array}{l}\text { Percentage deviations } \\
\Delta_{l m}^{i}\end{array}$} \\
\hline & $\Delta_{y}^{i}$ & $\Delta_{l m}^{i}$ & $\Delta_{y}^{i}$ & $\Delta_{l m}^{i}$ & $\Delta_{y}^{i}$ & $\Delta_{l m}^{i}$ & EZ-GR (\%) & EZ-SP (\%) & EZ-GR (\%) & EZ-SP (\%) \\
\hline 1 & 0.79 & 0.37 & 0.87 & 0.37 & 1.02 & 0.31 & 29.2 & 16.7 & -17.0 & -15.9 \\
\hline 2 & 1.07 & 0.46 & 1.21 & 0.24 & 1.16 & 0.21 & 8.4 & -4.3 & -54.5 & -13.6 \\
\hline 3 & 0.89 & 0.28 & 0.82 & 0.60 & 0.97 & 0.41 & 8.6 & 18.6 & 46.8 & -31.1 \\
\hline 4 & 0.17 & 0.92 & 0.21 & 0.89 & 0.23 & 0.85 & 34.9 & 5.1 & -7.3 & -4.0 \\
\hline 5 & 0.77 & 0.53 & 0.91 & 0.48 & 1.18 & 0.31 & 53.3 & 29.8 & -42.1 & -36.2 \\
\hline 6 & 0.40 & 0.81 & 0.46 & 0.77 & 0.73 & 0.60 & 83.0 & 58.3 & -26.5 & -23.1 \\
\hline 7 & 0.79 & 0.73 & 1.00 & 0.58 & 1.19 & 0.33 & 50.2 & 18.6 & -54.9 & -43.1 \\
\hline 8 & 0.40 & 0.85 & 0.80 & 0.59 & 1.11 & 0.37 & 180.0 & 38.3 & -56.0 & -36.7 \\
\hline 9 & 1.02 & 0.56 & 1.37 & 0.37 & 1.39 & 0.24 & 37.0 & 1.8 & -56.5 & -35.3 \\
\hline 10 & 0.23 & 0.86 & 0.16 & 0.91 & 0.37 & 0.76 & 62.1 & 135.7 & -11.7 & -16.2 \\
\hline 11 & 0.28 & 0.86 & 0.58 & 0.69 & 0.93 & 0.45 & 233.2 & 62.2 & -47.2 & -34.4 \\
\hline 12 & 0.28 & 0.85 & 0.38 & 0.81 & 0.83 & 0.49 & 196.9 & 118.6 & -42.3 & -39.3 \\
\hline 13 & 0.50 & 0.77 & 0.76 & 0.64 & 1.11 & 0.40 & 123.3 & 46.4 & -48.3 & -37.8 \\
\hline 14 & 0.75 & 0.65 & 1.05 & 0.53 & 1.20 & 0.34 & 59.0 & 13.8 & -48.0 & -36.1 \\
\hline 15 & 0.55 & 0.72 & 0.71 & 0.66 & 0.86 & 0.53 & 56.9 & 20.6 & -27.5 & -20.0 \\
\hline 16 & 0.84 & 0.60 & 0.95 & 0.59 & 1.27 & 0.33 & 51.9 & 34.1 & -45.1 & -44.5 \\
\hline 17 & 0.07 & 0.98 & 0.22 & 0.89 & 0.51 & 0.75 & 598.3 & 134.4 & -23.9 & -16.5 \\
\hline 18 & 0.41 & 0.78 & 0.60 & 0.71 & 0.96 & 0.47 & 135.2 & 61.4 & -39.7 & -33.2 \\
\hline 19 & 0.41 & 0.83 & 0.60 & 0.72 & 1.10 & 0.42 & 168.4 & 83.3 & -49.6 & -42.1 \\
\hline 20 & 0.16 & 0.93 & 0.55 & 0.76 & 1.06 & 0.44 & 573.0 & 93.2 & -53.1 & -42.5 \\
\hline 21 & 0.06 & 1.00 & 0.68 & 0.68 & 0.84 & 0.56 & 1217.9 & 24.1 & -43.7 & -17.3 \\
\hline 22 & 0.44 & 0.78 & 0.75 & 0.66 & 0.95 & 0.48 & 114.1 & 26.2 & -38.4 & -26.2 \\
\hline 23 & 0.99 & 0.13 & 1.29 & 0.38 & 1.39 & 0.28 & 40.4 & 7.9 & 115.0 & -27.0 \\
\hline 24 & 0.77 & 0.49 & 0.88 & 0.40 & 0.94 & 0.37 & 21.2 & 7.0 & -25.9 & -8.6 \\
\hline 25 & 1.33 & 0.37 & 1.24 & 0.35 & 1.33 & 0.17 & 0.2 & 7.8 & -54.8 & -52.3 \\
\hline 26 & 1.02 & 0.43 & 1.02 & 0.50 & 1.29 & 0.24 & 26.7 & 27.4 & -45.2 & -52.6 \\
\hline 27 & 1.04 & 0.40 & 1.30 & 0.36 & 1.40 & 0.22 & 34.2 & 7.3 & -45.7 & -39.8 \\
\hline 28 & 1.24 & 0.24 & 1.32 & 0.37 & 1.50 & 0.20 & 21.2 & 13.7 & -18.2 & -46.1 \\
\hline 29 & 1.16 & 0.39 & 1.47 & 0.33 & 1.41 & 0.19 & 20.9 & -4.1 & -50.8 & -41.9 \\
\hline 30 & 1.31 & 0.29 & 1.51 & 0.27 & 1.49 & 0.16 & 13.7 & -0.8 & -45.7 & -41.6 \\
\hline 31 & 1.12 & 0.35 & 1.18 & 0.42 & 1.37 & 0.24 & 22.3 & 16.6 & -31.7 & -43.3 \\
\hline 32 & 0.91 & 0.36 & 1.09 & 0.40 & 1.11 & 0.28 & 21.5 & 1.5 & -21.5 & -30.1 \\
\hline 33 & 0.84 & 0.50 & 1.06 & 0.54 & 1.01 & 0.47 & 20.8 & -4.8 & -7.0 & -13.5 \\
\hline 34 & 0.50 & 0.74 & 1.32 & 0.36 & 1.29 & 0.27 & 159.0 & -2.2 & -63.8 & -24.9 \\
\hline 35 & 1.26 & 0.48 & 1.71 & 0.39 & 1.67 & 0.26 & 32.9 & -2.5 & -46.8 & -35.0 \\
\hline 36 & 1.05 & 0.33 & 1.25 & 0.30 & 1.33 & 0.18 & 27.5 & 6.3 & -44.4 & -39.1 \\
\hline 37 & 1.00 & 0.54 & 1.19 & 0.46 & 1.36 & 0.21 & 35.5 & 13.8 & -61.6 & -55.7 \\
\hline 38 & 1.09 & 0.47 & 1.25 & 0.34 & 1.28 & 0.21 & 17.5 & 2.0 & -55.1 & -37.4 \\
\hline 39 & 1.16 & 0.24 & 1.05 & 0.29 & 1.18 & 0.20 & 1.8 & 11.8 & -16.5 & -30.8 \\
\hline 40 & 1.10 & 0.42 & 1.38 & 0.41 & 1.50 & 0.23 & 36.5 & 8.7 & -44.6 & -42.6 \\
\hline 41 & 1.25 & 0.36 & 1.44 & 0.31 & 1.36 & 0.19 & 8.8 & -5.3 & -47.3 & -38.9 \\
\hline 42 & 0.97 & 0.43 & 1.30 & 0.24 & 1.39 & 0.21 & 43.2 & 7.1 & -51.9 & -13.1 \\
\hline 43 & 1.33 & 0.29 & 1.30 & 0.26 & 1.42 & 0.18 & 6.4 & 9.7 & -37.3 & -32.2 \\
\hline 44 & 1.34 & 0.18 & 1.09 & 0.07 & 0.50 & -0.03 & -62.6 & -54.2 & -115.6 & -138.0 \\
\hline 45 & 1.25 & 0.29 & 1.43 & 0.33 & 1.34 & 0.21 & 7.3 & -6.7 & -28.3 & -36.3 \\
\hline 46 & 1.11 & 0.31 & 1.37 & 0.38 & 1.40 & 0.21 & 25.5 & 1.6 & -29.8 & -43.7 \\
\hline 47 & 1.31 & 0.43 & 1.41 & 0.30 & 1.39 & 0.32 & 6.6 & -1.2 & -25.5 & 7.9 \\
\hline
\end{tabular}


Table 1 (continued)

\begin{tabular}{|c|c|c|c|c|c|c|c|c|c|c|}
\hline \multirow[t]{2}{*}{$i$} & \multicolumn{2}{|l|}{ GR } & \multicolumn{2}{|l|}{ SP } & \multicolumn{2}{|l|}{ EZ } & \multicolumn{2}{|c|}{$\begin{array}{l}\text { Percentage deviations } \\
\Delta_{y}^{i}\end{array}$} & \multicolumn{2}{|c|}{$\begin{array}{l}\text { Percentage deviations } \\
\Delta_{l m}^{i}\end{array}$} \\
\hline & $\Delta_{y}^{i}$ & $\Delta_{l m}^{i}$ & $\Delta_{y}^{i}$ & $\Delta_{l m}^{i}$ & $\Delta_{y}^{i}$ & $\Delta_{I m}^{i}$ & EZ-GR (\%) & EZ-SP (\%) & EZ-GR (\%) & EZ-SP (\%) \\
\hline 48 & 1.20 & 0.36 & 1.37 & 0.39 & 1.25 & 0.27 & 4.5 & -8.7 & -23.8 & -30.8 \\
\hline 49 & 1.16 & 0.33 & 1.43 & 0.30 & 1.13 & 0.24 & -3.0 & -21.1 & -25.4 & -19.0 \\
\hline 50 & 1.00 & 0.32 & 0.89 & 0.43 & 0.91 & 0.30 & -8.4 & 2.1 & -5.4 & -29.2 \\
\hline 51 & 1.70 & 0.39 & 1.91 & 0.39 & 1.89 & 0.20 & 11.5 & -1.0 & -49.0 & -49.2 \\
\hline 52 & 1.15 & 0.38 & 1.26 & 0.38 & 1.32 & 0.23 & 14.7 & 4.9 & -39.7 & -40.2 \\
\hline 53 & 1.43 & 0.37 & 1.53 & 0.46 & 1.50 & 0.23 & 5.0 & -1.9 & -37.2 & -49.6 \\
\hline 54 & 1.50 & 0.35 & 1.68 & 0.34 & 1.67 & 0.19 & 11.1 & -0.7 & -46.9 & -45.9 \\
\hline 55 & 1.66 & 0.35 & 1.77 & 0.36 & 1.87 & 0.18 & 12.6 & 5.7 & -48.1 & -48.7 \\
\hline 56 & 1.18 & 0.29 & 1.52 & 0.41 & 1.55 & 0.17 & 31.3 & 1.8 & -42.1 & -58.3 \\
\hline 57 & 1.25 & 0.53 & 1.56 & 0.39 & 1.81 & 0.19 & 45.4 & 15.8 & -63.9 & -50.3 \\
\hline 58 & 1.06 & 0.20 & 1.32 & 0.28 & 1.37 & 0.18 & 29.0 & 4.2 & -12.3 & -37.3 \\
\hline 59 & 1.37 & 0.37 & 1.57 & 0.36 & 1.48 & 0.17 & 8.1 & -6.1 & -55.6 & -54.0 \\
\hline 60 & 1.37 & 0.43 & 1.54 & 0.44 & 1.75 & 0.20 & 27.2 & 13.9 & -53.2 & -54.6 \\
\hline 61 & 0.96 & 0.15 & 1.34 & 0.45 & 1.41 & 0.22 & 46.5 & 5.0 & 43.3 & -52.1 \\
\hline 62 & 1.33 & 0.21 & 1.18 & 0.29 & 1.25 & 0.13 & -5.9 & 6.5 & -40.2 & -55.5 \\
\hline 63 & 1.93 & 0.45 & 2.02 & 0.41 & 2.11 & 0.20 & 9.6 & 4.6 & -56.9 & -52.3 \\
\hline TE & 0.95 & 0.49 & 1.13 & 0.46 & 1.24 & 0.30 & 29.9 & 9.1 & -38.9 & -34.5 \\
\hline
\end{tabular}

follows that, for all economies under consideration, there are a significant negative linear correlation between the output and import multipliers, and a significant positive linear correlation between the output and total employment multipliers. However, in the case of the Greek economy, the former correlation is more intense, while the latter is less intense. These findings are in accordance with the figures reported in Table 2, which show that the secondary employment effects are significantly weaker in the Greek economy.

2. Unfavorable multiplier values are concentrated in industrial commodities, whereas favorable multiplier values are concentrated in service commodities. This view is further supported by the figures in Tables 4 and 5 .

Table 4 reports the arithmetic means of multipliers for the primary production, industrial and service commodities, and commodities that are primarily related to government activities (i.e., commodities 54-57; see Appendix 1), while the figures in parentheses indicate the percentage deviations of the sectoral multiplier values from those of the total economy. It seems that these findings (in combination with those reported in Tables 1,2) are not in contrast with the observed recessions of the Greek and Spanish economies and, to the extent that they correspond to reality, reveal the intersectoral dimensions of these prolonged recessions. At the same time, they do not contradict those of some other studies (although using quite different frameworks): for instance, in October 2012, the International Monetary Fund (2012, pp. 41-43) stated that the projections for the measures applied and/or proposed (from 2010 onwards) to the Greek economy were based on the false premise that the fiscal multiplier was around 0.50, while the 'actual' fiscal multiplier is in the range of 0.90-1.70 (also see Blanchard and Leigh 2013). And De Cos and Moral-Benito (2016), applying a smooth transition vector 


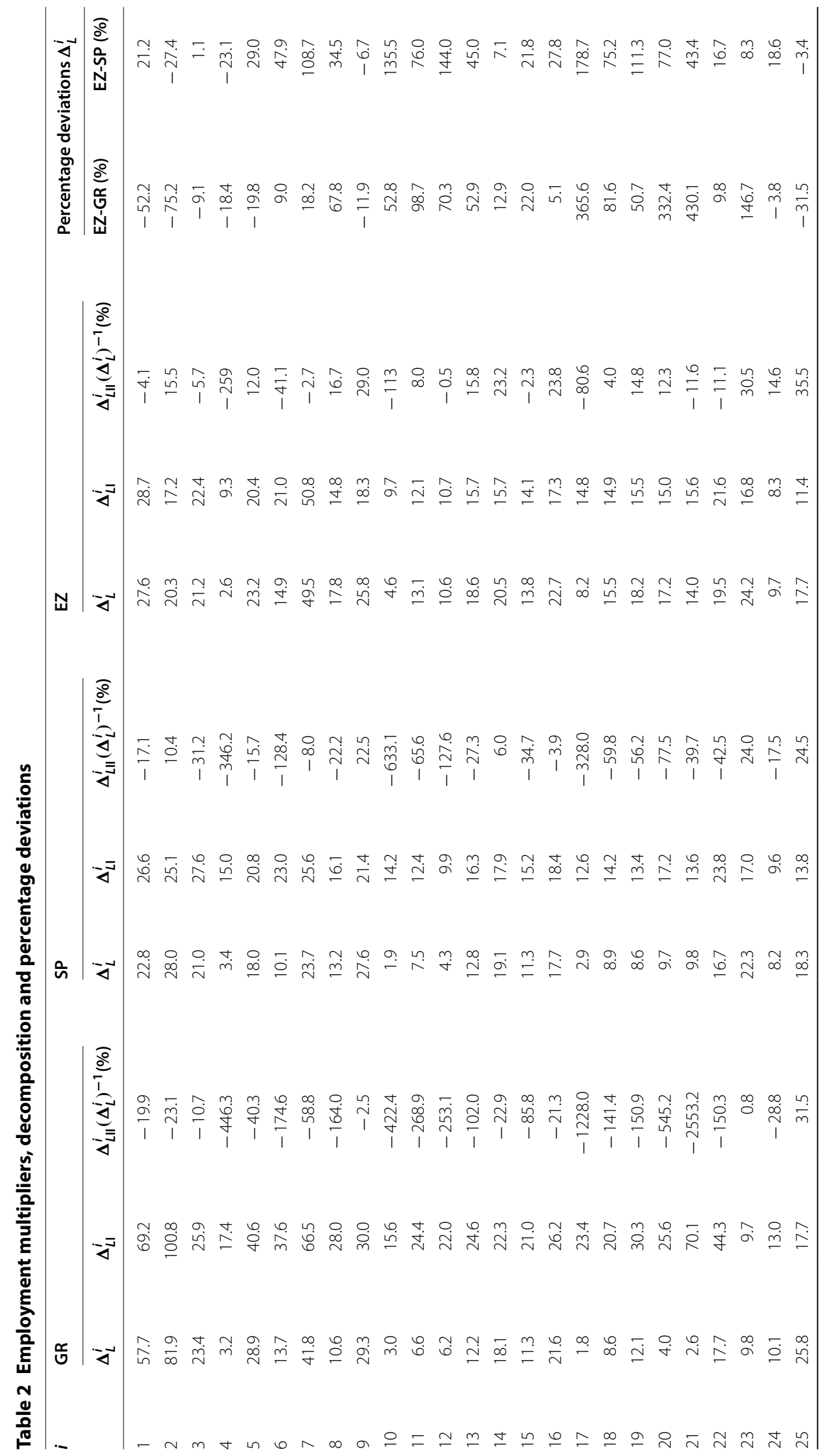




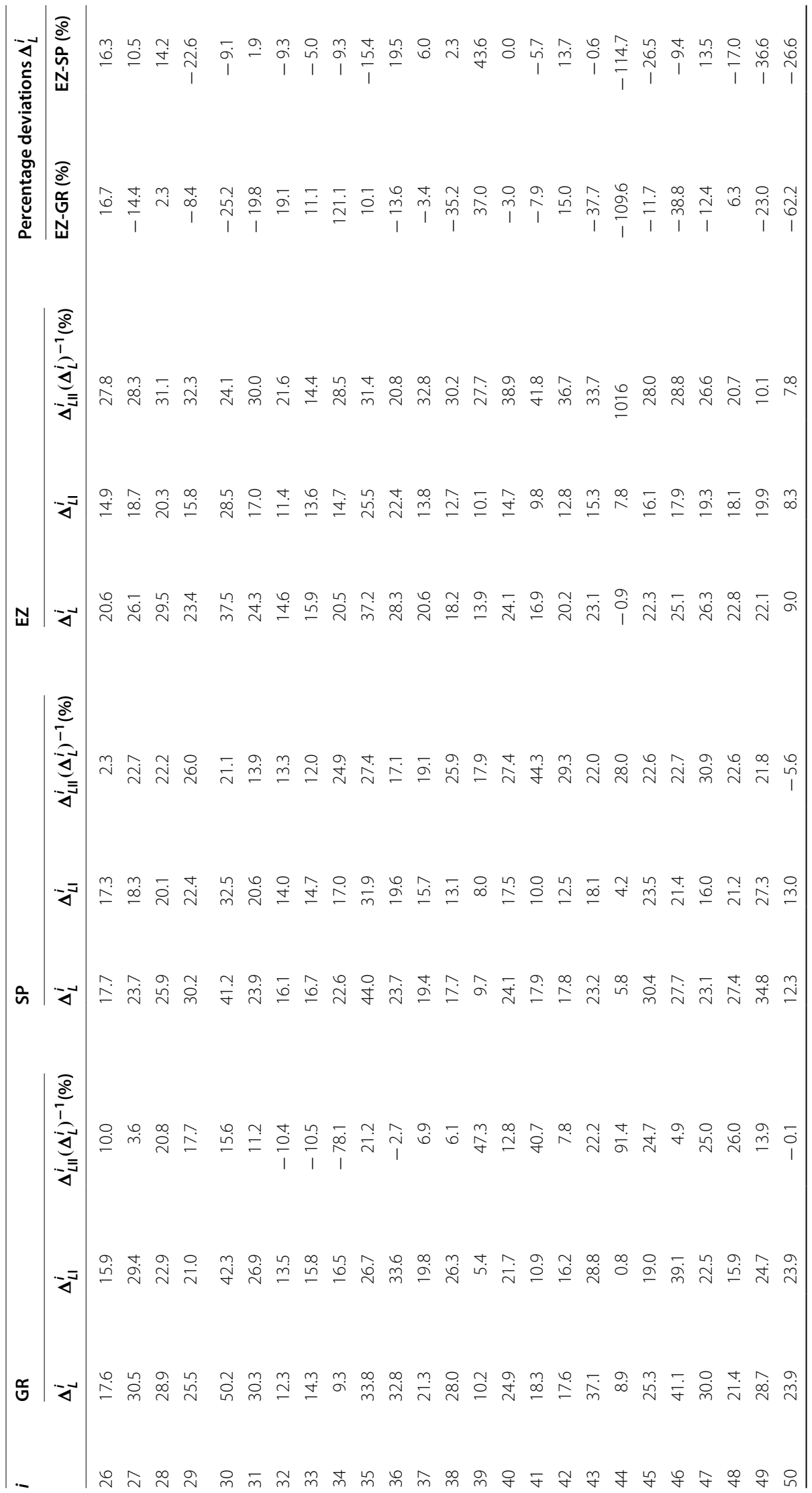




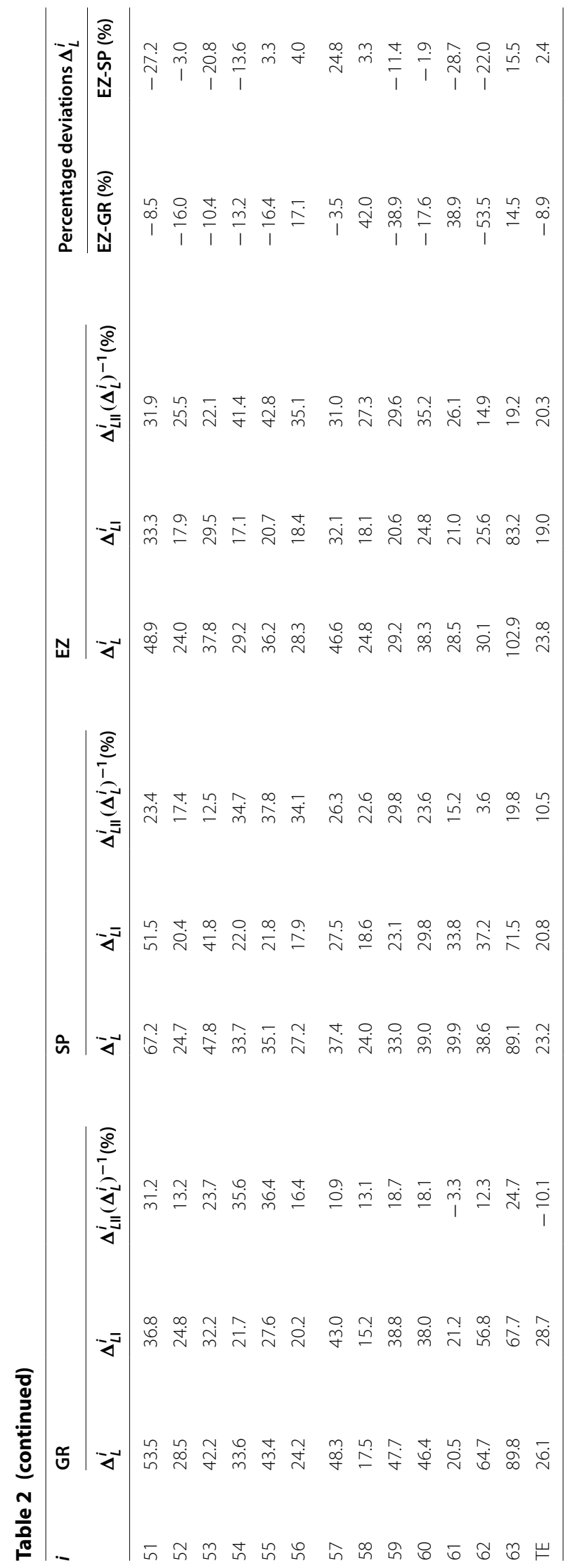


Table 3 Correlation matrix between output, import and total employment multipliers

\begin{tabular}{|c|c|c|c|c|c|c|c|c|c|}
\hline & \multicolumn{3}{|l|}{$\Delta_{l m}^{i}$} & \multicolumn{3}{|l|}{$\Delta_{y}^{i}$} & \multicolumn{3}{|l|}{$\Delta_{L}^{i}$} \\
\hline & EZ & GR & SP & EZ & GR & SP & EZ & GR & SP \\
\hline \multicolumn{10}{|l|}{$\Delta_{I m}^{i}$} \\
\hline$E Z$ & 1.00 & & & & & & & & \\
\hline$G R$ & 0.80 & 1.00 & & & & & & & \\
\hline SP & 0.91 & 0.84 & 1.00 & & & & & & \\
\hline \multicolumn{10}{|l|}{$\Delta_{y}^{i}$} \\
\hline$E Z$ & -0.72 & -0.53 & -0.58 & 1.00 & & & & & \\
\hline$G R$ & -0.83 & -0.82 & -0.80 & 0.78 & 1.00 & & & & \\
\hline $\mathrm{SP}$ & -0.82 & -0.71 & -0.79 & 0.90 & 0.91 & 1.00 & & & \\
\hline \multicolumn{10}{|l|}{$\Delta_{L}^{i}$} \\
\hline EZ & -0.41 & -0.27 & -0.28 & 0.78 & 0.61 & 0.67 & 1.00 & & \\
\hline$G R$ & -0.53 & -0.44 & -0.50 & 0.64 & 0.70 & 0.65 & 0.76 & 1.00 & \\
\hline $\mathrm{SP}$ & -0.54 & -0.47 & -0.46 & 0.81 & 0.76 & 0.82 & 0.90 & 0.80 & 1.00 \\
\hline
\end{tabular}

autoregression (STVAR) model, estimated Spain's fiscal multiplier at 1.40 for crisis (or turbulent) times and 0.60 for tranquil times. ${ }^{10}$

Finally, Table 5 reports the percentage deviations and the 'mean absolute deviation' (MAD) of the EZ sectoral multipliers from those of the Greek and Spanish economies. The figures suggest that the most remarkable deviations between the EZ and these two Southern Europe economies are, firstly, in the industry sector and, secondly, in the import dependencies of the government activity sector. ${ }^{11}$ Nevertheless, the high value of the total employment multiplier (relative to the value of the output multiplier) for the Greek primary sector is also noticeable and rather indicates the low labor productivity (measured by $\bar{\Delta}_{y}^{i}\left(\bar{\Delta}_{L}^{i}\right)^{-1}$ ) of this sector.

3. Tables 1 and 2 also indicate that, in each economy, there are, on the one hand, commodities simultaneously characterized by output, import and total employment multipliers that are better from those of the total economy, and, on the other hand, commodities simultaneously characterized by output, import and total employment multipliers that are worse from those of the total economy. These findings could provide a basis for formulating well-targeted, scheduled and country-specific policy programs. $^{12}$

\footnotetext{
${ }^{10}$ Charles et al. (2015) and Charles (2016) argue, both empirically (also especially regarding Southern Eurozone economies) and theoretically (within aggregate post-Keynesian-Kaleckian models), that, during important recessions, decreases in the savings ratio out of profits and/or the propensity to import are large enough to increase the fiscal multiplier value.

11 According to evidence on the 'intersectoral linkages and leakages' in the Greek economy, for the years 2005 and 2010 provided by Leriou et al. (2016) and Mariolis (2018b), the industry sector is the 'weak link' in this economy. Also see the evidence on the commodity multipliers, for the period 2000-2010, provided by Ntemiroglou (2016). The totality of those findings probably suggests that the structural features of the Greek economy have been shaped well before the emergence of the so-called Eurozone crisis.

12 In order to further analyze the demand management capabilities, the actual (reported in the SUTs) compositions of autonomous demand should be taken into account (see Mariolis and Soklis 2018, pp. 127-131).
} 


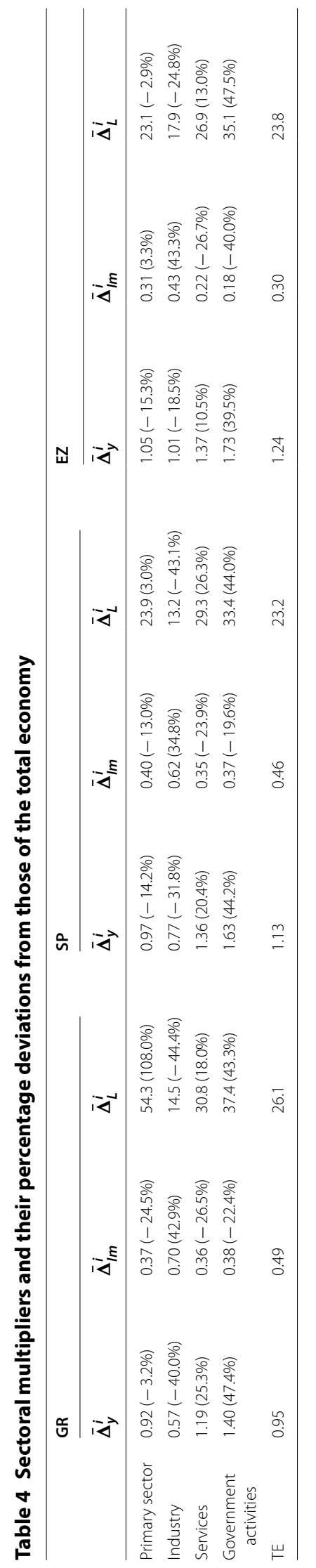


Table 5 Percentage deviations of the EZ sectoral multipliers from those of the Greek and Spanish economies

\begin{tabular}{|c|c|c|c|c|c|c|}
\hline & \multicolumn{2}{|c|}{ Percentage deviations $\bar{\Delta}_{y}^{i}$} & \multicolumn{2}{|c|}{$\begin{array}{l}\text { Percentage deviations } \\
\bar{\Delta}_{l m}^{i}\end{array}$} & \multicolumn{2}{|c|}{$\begin{array}{l}\text { Percentage deviations } \\
\bar{\Delta}_{L}^{i}\end{array}$} \\
\hline & EZ-GR (\%) & EZ-SP (\%) & EZ-GR (\%) & EZ-SP (\%) & EZ-GR (\%) & EZ-SP (\%) \\
\hline Primary sector & 14.1 & 8.2 & -16.2 & -22.5 & -57.5 & -3.3 \\
\hline Industry & 77.2 & 31.2 & -38.6 & -30.6 & 23.4 & 35.6 \\
\hline Services & 15.1 & 0.7 & -38.8 & -37.1 & -12.7 & -8.2 \\
\hline Government activities & 23.5 & 6.1 & -52.6 & -51.4 & -6.1 & 5.1 \\
\hline MAD & 35.5 & 13.4 & 31.2 & 30.1 & 31.2 & 15.7 \\
\hline
\end{tabular}

The MAD refers to the three main sectors of the economies

Nevertheless, since both the Greek and Spanish economies faced serious external imbalances and should strengthen their extraversion and export performance (consider, e.g., Oelgemöller 2013; Collignon and Esposito 2017), we then focus exclusively on the tradable sectors (see Appendix 1; Table 7) and combine the output, import and total employment multipliers into the following composite index (of Cobb-Douglas type) for each tradable commodity:

$$
C I^{i} \equiv\left(\Delta O^{i}\right)^{\alpha}\left(\Delta E^{i}\right)^{1-\alpha}
$$

where $\Delta O^{i} \equiv \Delta_{y}^{i}\left(\Delta_{I m}^{i}\right)^{-1}$ and $\Delta E^{i} \equiv \Delta_{L}^{i}\left(\Delta_{I m}^{i}\right)^{-1}$ are the indices of output and total employment multiplier effects relative to import multiplier effects, respectively. Finally, by assigning quite different weights to the indices $\Delta O^{i}$ and $\Delta E^{i}$, i.e., by setting $\alpha=0.10$ and, alternatively, $\alpha=0.90$, we define as 'key-commodities' (as 'anti-key-commodities') the commodities ranked in the top ten (in the bottom ten) positions according to both values of $C I^{i}$.

The results are reported in Table 6, where the numbers in parentheses indicate the rank order according to the two values of $\mathrm{CI}^{i}$, while commodities which are common among the economies under consideration are denoted by italic characters. Thus, it is observed that, in all economies, the vast majority of key-commodities belong to services, while the vast majority of anti-key-commodities belong to industry and tend to be common across these three economies.

\section{Conclusions}

Using input-output data from the Supply and Use Tables for the year 2010 and a joint production framework, this paper estimated the static output, import and employment multipliers for the Greek, Spanish and Eurozone economies. It has been detected that:

1. Although both Southern economies diverge to a considerable extent from the EZ economy, the latter is, however, more correlated with the Spanish economy rather than with the Greek one. This differentiated correlation probably results from, firstly, the heavy, both direct and indirect, dependence of the Greek industry sector on imports and, secondly, the high value of the total employment multiplier for the Greek primary sector. 
Table 6 Key and anti-key tradable commodities

\begin{tabular}{|c|c|c|c|c|c|c|c|}
\hline \multirow[t]{2}{*}{$i$} & \multicolumn{3}{|c|}{ Key-commodities } & \multirow[t]{2}{*}{$i$} & \multicolumn{3}{|c|}{ Anti-key-commodities } \\
\hline & GR & SP & EZ & & GR & SP & $\mathrm{EZ}$ \\
\hline 1 & - & $(10,10)$ & - & 4 & $(34,27)$ & $(32,25)$ & $(39,32)$ \\
\hline 2 & $(1,10)$ & $(2,1)$ & $(9,9)$ & 6 & - & $(28,23)$ & $(35,29)$ \\
\hline 3 & $(7,6)$ & - & - & 8 & $(28,24)$ & - & - \\
\hline 29 & - & - & $(4,1)$ & 10 & $(33,26)$ & $(34,26)$ & $(38,31)$ \\
\hline 34 & - & $(8,4)$ & - & 11 & $(30,25)$ & $(30,21)$ & $(31,26)$ \\
\hline 35 & - & - & $(2,4)$ & 12 & $(31,25)$ & $(31,24)$ & $(36,27)$ \\
\hline 40 & - & $(9,6)$ & $(7,7)$ & 13 & - & $(25,18)$ & - \\
\hline 41 & - & $(9,2)$ & $(10,2)$ & 15 & - & $(26,19)$ & $(33,27)$ \\
\hline 42 & - & - & $(8,5)$ & 17 & $(36,28)$ & $(33,25)$ & $(37,30)$ \\
\hline 45 & $(5,2)$ & $(4,2)$ & $(6,7)$ & 18 & $(29,23)$ & $(28,21)$ & - \\
\hline 46 & $(4,3)$ & $(5,4)$ & $(5,6)$ & 19 & - & $(29,21)$ & - \\
\hline 47 & $(10,9)$ & - & - & 20 & $(20,27)$ & $(28,22)$ & - \\
\hline 48 & - & $(6,5)$ & - & 21 & $(35,28)$ & $(27,20)$ & $(34,28)$ \\
\hline 49 & $(6,4)$ & - & - & 24 & - & - & $(32,24)$ \\
\hline 50 & $(9,7)$ & - & - & 34 & $(27,21)$ & - & - \\
\hline 52 & $(8,8)$ & $(7,6)$ & - & Total number & 10 & 12 & 9 \\
\hline 53 & - & $(3,5)$ & $(1,3)$ & & & & \\
\hline 61 & $(3,1)$ & - & - & & & & \\
\hline 62 & - & $(1,3)$ & - & & & & \\
\hline Total number & 9 & 11 & 9 & & & & \\
\hline
\end{tabular}

2. The relatively high import dependencies of both the Greek and Spanish government activity sectors are noticeable. Nevertheless, in all the economies considered, the government activity sectors are characterized by favorable values for the output and employment multipliers, casting doubt, therefore, on the fiscal consolidation measures implemented. The possibility of reallocating government consumption and investment expenditures to mitigate the recession's impacts should be taken into account.

3. With regard to the tradable sectors, extreme unfavorable multiplier values tend to be concentrated in certain industrial commodities, whereas extreme favorable multiplier values are dispersed among various service and primary production commodities. This two-sided finding suggests that effective demand management policies are necessary but not sufficient for resetting the Eurozone system on viable paths of recovery. It rather calls, on the one hand, for a common intra-Eurozone industrial and trade policy reform, and, on the other hand, for per country and commodityspecific demand policies.

Future research work should use post-2014 input-output data, gradually include all the Eurozone (or even the European Union) economies, incorporate explicitly both the direct and indirect taxation sides of the fiscal system and explore the effects of the actual internal devaluation policies on the multiplier processes.

Authors' contributions

Authors TM, NN and GS have equally contributed to designing the research, the process of data collection and calculation as well as to writing the manuscript. All authors have read and approved the final manuscript. 


\begin{abstract}
Author details
${ }^{1}$ Department of Public Administration, Panteion University, Athens, Greece. ${ }^{2}$ School of Applied Mathematical and Physical Sciences, National Technical University of Athens, Athens, Greece.
\end{abstract}

\title{
Acknowledgements
}

A first version of this paper was presented at a Workshop of the 'Study Group on Sraffian Economics' at the Panteion University, in November 2016: we would like to thank Eirini Leriou, Maria Pantzartzidou and Nikolaos Rodousakis for helpful comments and suggestions. Furthermore, we are indebted to Thomas Moutos for many insightful discussions and the proposed identification of the 'key and anti-key-commodities' that appears in this paper.

Competing interests

The material in the manuscript has been acquired according to modern ethical standards and does not contain material copied from anyone else without their written permission, and there is no conflict of interest.

\section{Availability of data and materials}

The Supply and Use Tables (SUTS) and the corresponding levels of employment of the Greek, Spanish and Eurozone economies are provided via the Hellenic Statistical Authority, Spanish Statistical Office and Eurostat websites, respectively: http://www.statistics.gr/en/statistics/-/publication/SEL38/2010; http://www.statistics.gr/en/statistics/-/publication/ SEL21/2016; http://www.ine.es/dyngs/INEbase/en/operacion.htm?c=Estadistica_C\&cid=1254736165950\&menu=resul tados\&secc =1254736195578\&idp=1254735576581; http://ec.europa.eu/eurostat/web/esa-supply-use-input-tables/ data/workbooks; and http://appsso.eurostat.ec.europa.eu/nui/show.do?dataset=nama_nace64_e\&lang=en.

Funding

Not applicable.

\section{Appendix 1: Data sources and construction of variables}

The available SUTs describe 65 products and industries. However, the elements associated with the commodity 'Services provided by extraterritorial organisations and bodies' are all equal to zero and, therefore, we remove them from our analysis. Moreover, since the labor input in the industry 'Imputed rents of owner-occupied dwellings' equals zero, we aggregate it with the industry 'Real estate activities excluding imputed rent.' Thus, we derive SUTs that describe 63 products.

The described products and their correspondence to CPA (Classification of Products by Activity) are reported in Table 7, where the products 1-3 belong to 'Primary production.' The products 4-27 belong to 'Industry': (1) the product 4 corresponds to 'Mining and quarrying'; (2) the products 5-23 correspond to 'Processing products'; (3) the product 24 corresponds to 'Energy'; (4) the products 25 and 26 correspond to 'Water supply and waste disposal'; and (5) the product 27 corresponds to 'Construction'. Finally, the products $28-63$ belong to 'Services', while the products 54-57 are primarily related to government activities.

In the last column of Table 7, the symbol ' $v$ ' indicates the 'tradable commodities'. They are conventionally defined as commodities for which the ratio of total trade (exports plus imports) to gross domestic production, i.e., the 'openness ratio', is in the order of $10 \%$ or more (see De Gregorio et al. 1994; Piton 2017). It is noted, however, that, in the case of the Greek economy, the products 36 ('Accommodation and food services') and 52 ('Travel agency, tour operator and other reservation services and related services'), which are related to tourism activities, display zero exports and imports because the relevant SUTs record only the total travel receipts and payments and not the respective payments for each commodity. These exports-receipts 
Table 7 Product classification and tradable commodities

\begin{tabular}{|c|c|c|c|c|c|}
\hline \multirow[t]{2}{*}{ No. } & \multirow[t]{2}{*}{ CPA } & \multirow[t]{2}{*}{ Nomenclature } & \multicolumn{3}{|c|}{$\begin{array}{l}\text { Tradable } \\
\text { commodities }\end{array}$} \\
\hline & & & GR & SP & $\mathrm{EZ}$ \\
\hline 1 & A01 & Products of agriculture, hunting and related services & $\vee$ & V & V \\
\hline 2 & $\mathrm{~A} 02$ & Products of forestry, logging and related services & $\vee$ & V & V \\
\hline 3 & $\mathrm{~A} 03$ & $\begin{array}{l}\text { Fish and other fishing products; aquaculture products; support } \\
\text { services to fishing }\end{array}$ & $\vee$ & V & $\vee$ \\
\hline 4 & B & Mining and quarrying & $\vee$ & V & $\vee$ \\
\hline 5 & $\mathrm{C} 10-\mathrm{C} 12$ & Food products, beverages and tobacco products & $\vee$ & V & V \\
\hline 6 & $\mathrm{C} 13-\mathrm{C} 15$ & Textiles, wearing apparel and leather products & $\vee$ & V & $\vee$ \\
\hline 7 & C16 & $\begin{array}{l}\text { Wood and of products of wood and cork, except furniture; articles } \\
\text { of straw and plaiting materials }\end{array}$ & $\vee$ & V & $\vee$ \\
\hline 8 & C17 & Paper and paper products & $\vee$ & V & $\vee$ \\
\hline 9 & C18 & Printing and recording services & - & - & - \\
\hline 10 & C19 & Coke and refined petroleum products & V & V & V \\
\hline 11 & C20 & Chemicals and chemical products & $\vee$ & $\vee$ & $\vee$ \\
\hline 12 & C21 & Basic pharmaceutical products and pharmaceutical preparations & V & V & V \\
\hline 13 & $\mathrm{C} 22$ & Rubber and plastics products & V & V & V \\
\hline 14 & C23 & Other non-metallic mineral products & V & $\vee$ & V \\
\hline 15 & C24 & Basic metals & V & V & V \\
\hline 16 & $\mathrm{C} 25$ & Fabricated metal products, except machinery and equipment & V & V & V \\
\hline 17 & C26 & Computer, electronic and optical products & V & V & V \\
\hline 18 & $\mathrm{C} 27$ & Electrical equipment & $\vee$ & V & $\vee$ \\
\hline 19 & C28 & Machinery and equipment n.e.c. & V & $\vee$ & V \\
\hline 20 & C29 & Motor vehicles, trailers and semi-trailers & V & V & V \\
\hline 21 & C30 & Other transport equipment & V & $\vee$ & $\vee$ \\
\hline 22 & $\mathrm{C} 31-\mathrm{C} 32$ & Furniture; other manufactured goods & $\vee$ & V & V \\
\hline 23 & C33 & Repair and installation services of machinery and equipment & - & - & - \\
\hline 24 & D35 & Electricity, gas, steam and air-conditioning & - & - & $\vee$ \\
\hline 25 & E36 & Natural water; water treatment and supply services & - & - & - \\
\hline 26 & E37-E39 & $\begin{array}{l}\text { Sewerage; waste collection, treatment and disposal activities; mate- } \\
\text { rials recovery; remediation activities and other waste manage- } \\
\text { ment services }\end{array}$ & V & V & V \\
\hline 27 & F & Constructions and construction works & - & - & - \\
\hline 28 & G45 & $\begin{array}{l}\text { Wholesale and retail trade and repair services of motor vehicles and } \\
\text { motorcycles }\end{array}$ & - & - & - \\
\hline 29 & G46 & Wholesale trade services, except of motor vehicles and motorcycles & - & - & $\vee$ \\
\hline 30 & G47 & Retail trade services, except of motor vehicles and motorcycles & - & - & - \\
\hline 31 & $\mathrm{H} 49$ & Land transport services and transport services via pipelines & - & V & - \\
\hline 32 & H50 & Water transport services & $\vee$ & $\vee$ & $\vee$ \\
\hline 33 & H51 & Air transport services & V & $\vee$ & $\vee$ \\
\hline 34 & H52 & Warehousing and support services for transportation & $\vee$ & $\vee$ & $\vee$ \\
\hline 35 & $\mathrm{H} 53$ & Postal and courier services & - & - & V \\
\hline 36 & I & Accommodation and food services & - & - & - \\
\hline 37 & $J 58$ & Publishing services & $\vee$ & $\vee$ & - \\
\hline 38 & J59-J60 & $\begin{array}{l}\text { Motion picture, video and television program production services, } \\
\text { sound recording and music publishing; programming and broad- } \\
\text { casting services }\end{array}$ & V & - & $\vee$ \\
\hline 39 & J61 & Telecommunications services & - & $\vee$ & $\vee$ \\
\hline 40 & $J 62-J 63$ & $\begin{array}{l}\text { Computer programming, consultancy and related services; informa- } \\
\text { tion services }\end{array}$ & $\vee$ & V & $\vee$ \\
\hline 41 & K64 & Financial services, except insurance and pension funding & $\vee$ & $\vee$ & v \\
\hline
\end{tabular}


Table 7 (continued)

\begin{tabular}{|c|c|c|c|c|c|}
\hline \multirow[t]{2}{*}{ No. } & \multirow[t]{2}{*}{ CPA } & \multirow[t]{2}{*}{ Nomenclature } & \multicolumn{3}{|c|}{$\begin{array}{l}\text { Tradable } \\
\text { commodities }\end{array}$} \\
\hline & & & GR & SP & $\mathrm{EZ}$ \\
\hline 42 & K65 & $\begin{array}{l}\text { Insurance, reinsurance and pension funding services, except com- } \\
\text { pulsory social security }\end{array}$ & $v$ & - & v \\
\hline 43 & K66 & Services auxiliary to financial services and insurance services & - & - & - \\
\hline 44 & L68A-L68B & Real estate activities & - & - & - \\
\hline 45 & M69-M70 & $\begin{array}{l}\text { Legal and accounting services; services of head offices; manage- } \\
\text { ment consulting services }\end{array}$ & $v$ & $v$ & v \\
\hline 46 & M71 & $\begin{array}{l}\text { Architectural and engineering services; technical testing and } \\
\text { analysis services }\end{array}$ & $v$ & $\vee$ & $v$ \\
\hline 47 & M72 & Scientific research and development services & $v$ & - & v \\
\hline 48 & M73 & Advertising and market research services & $v$ & $v$ & $v$ \\
\hline 49 & M74-M75 & $\begin{array}{l}\text { Other professional, scientific and technical services; veterinary } \\
\text { services }\end{array}$ & $v$ & - & $v$ \\
\hline 50 & N77 & Rental and leasing services & $v$ & $\vee$ & $\vee$ \\
\hline 51 & N78 & Employment services & - & - & - \\
\hline 52 & N79 & $\begin{array}{l}\text { Travel agency, tour operator and other reservation services and } \\
\text { related services }\end{array}$ & $v$ & 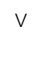 & - \\
\hline 53 & N80-N82 & $\begin{array}{l}\text { Security and investigation services; services to buildings and land- } \\
\text { scape; office administrative, office support and other business } \\
\text { support services }\end{array}$ & - & $v$ & $\vee$ \\
\hline 54 & $\mathrm{O} 84$ & $\begin{array}{l}\text { Public administration and defense services; compulsory social } \\
\text { security services }\end{array}$ & - & - & - \\
\hline 55 & P85 & Education services & - & - & - \\
\hline 56 & Q86 & Human health services & - & - & - \\
\hline 57 & Q87-Q88 & Social work services & - & - & - \\
\hline 58 & R90-R92 & $\begin{array}{l}\text { Creative, arts and entertainment services; library, archive, museum } \\
\text { and other cultural services; gambling and betting services }\end{array}$ & - & - & - \\
\hline 59 & R93 & Sporting services and amusement and recreation services & - & - & - \\
\hline 60 & 594 & Services furnished by membership organisations & - & - & - \\
\hline 61 & S95 & Repair services of computers and personal and household goods & $v$ & - & - \\
\hline 62 & 596 & Other personal services & - & $v$ & - \\
\hline \multirow[t]{2}{*}{63} & $\mathrm{~T}$ & $\begin{array}{l}\text { Services of households as employers; undifferentiated goods and } \\
\text { services produced by households for own use }\end{array}$ & - & - & - \\
\hline & & Total number of tradable commodities & 38 & 37 & 40 \\
\hline
\end{tabular}

(imports-payments) constitute the $19.4 \%$ (the $3.1 \%$ ) of the total exports (the total imports) of this economy. Thus, we decided to consider the commodity 52 as tradable in the Greek economy. ${ }^{13}$

The construction of the variables is as follows:

1. The price vector, $\mathbf{p}^{\mathrm{T}}$, is identified with $\mathbf{e}^{\mathrm{T}}$, i.e., the physical unit of measurement of each product is that unit which is worth of a monetary unit. (In the present SUTs, the unit is set to 1 million euro.)

2. The $63 \times 63$ Make and Use Matrices, which are directly obtained from the SUTs, are considered as the empirical counterpart of $\mathbf{B}$ and $\mathbf{A}$, respectively.

${ }^{13}$ The openness ratios of the product 36 are almost $6.0 \%$ (SP) and 4.3\% (EZ), while those of the product 52 are $18.5 \%$ (SP) and 3.3\% (EZ). 


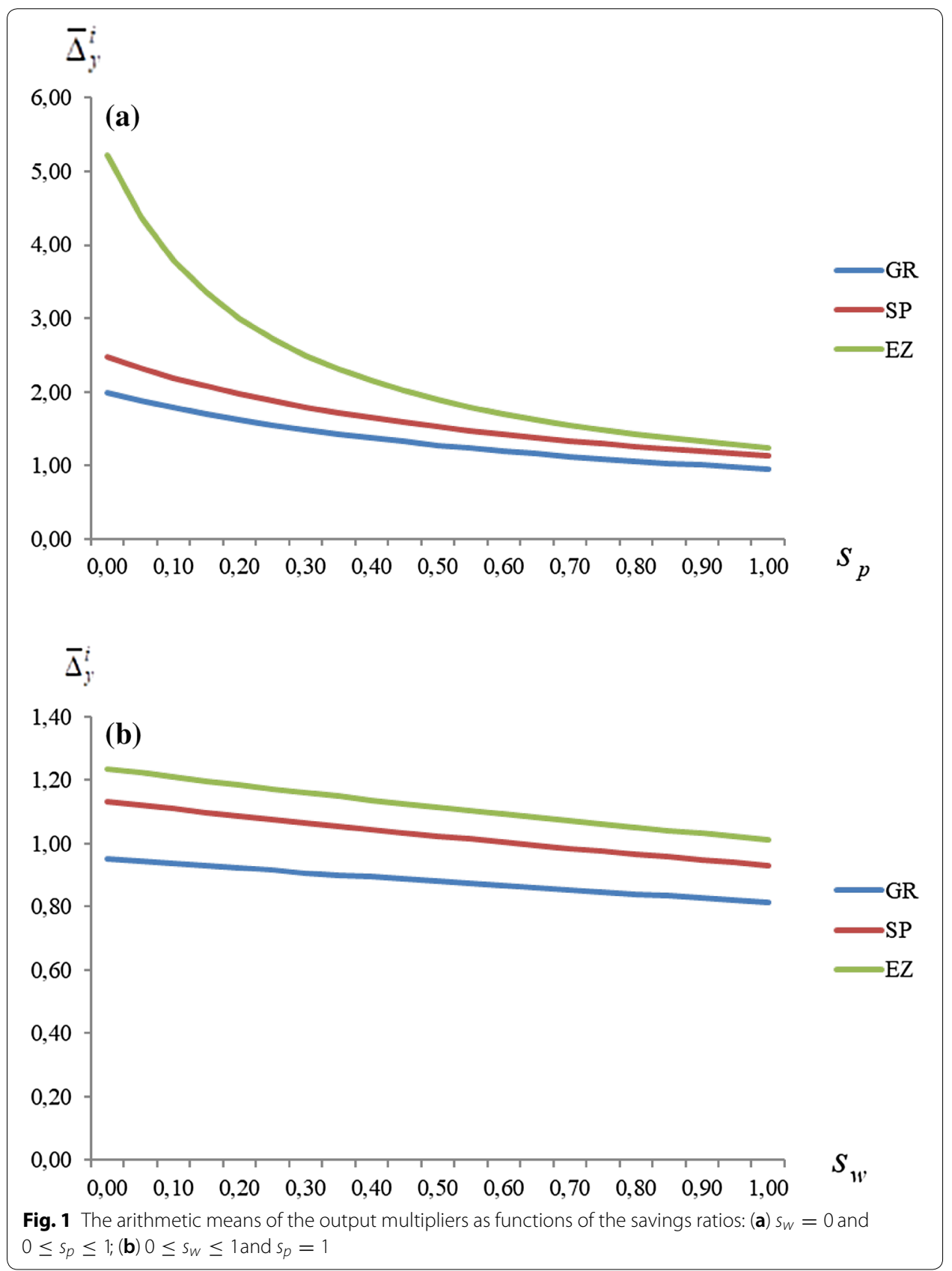

3. The $63 \times 1$ vector of consumption expenditures of the household sector, which is directly obtained from the Use Table, is considered as the empirical counterpart of $\mathbf{f}$.

4. The element 'Compensation of employees' from the Use Table, which is an element of the 'Value Added' of each industry, is considered as the empirical counterpart of total wages in industry $j, W_{j}$. Thus, the money wage rate for each industry is estimated as $w_{j}=W_{j} l_{j}^{-1}$, where $l_{j}$ denotes the total employment in the $j$ th industry.

5. The sectoral 'profit factors' are estimated from 


$$
1+r_{j}=\left[\left(\sum_{j=1}^{n} b_{j}\right)-w_{j} l_{j}\right]\left(\sum_{j=1}^{n} a_{j}\right)^{-1}
$$

6. The $63 \times 1$ vector of imports, which is directly obtained from the Use Table, is considered as the empirical counterpart of $\mathbf{I m}$. Thus, we may estimate the matrix $\hat{\mathbf{m}}$.

It should finally be stressed that, unlike the paper by Mariolis and Soklis (2018), we do not transform the Use Tables (which are measured in current 'purchasers' prices') into current 'basic prices' and, therefore, we take into account ad valorem taxes. Moreover, Mariolis and Soklis (2018) apply their framework to an earlier SUT of the Greek economy for the year 2010, provided via the Eurostat website. ${ }^{14}$ Thus, there are deviations between our and their empirical results for the Greek economy, which do not alter, however, the general picture of the structure of this economy.

\section{Appendix 2: The arithmetic means of the output multipliers as functions of the savings ratios}

The graphs in Fig. 1 display the arithmetic means of the output multipliers as functions of the savings ratios. Thus, it is observed that:

1. they are all strictly decreasing functions of the savings ratios (as in the case of singleproduct systems; see Kurz 1985, p. 133) and more sensitive to changes in the savings ratio out of profits; and

2. the arithmetic mean of the output multiplier for the EZ economy is no less than 1, regardless of the values of the savings ratios.

\section{Publisher's Note}

Springer Nature remains neutral with regard to jurisdictional claims in published maps and institutional affiliations.

Received: 29 November 2017 Accepted: 6 July 2018

Published online: 26 July 2018

\section{References}

Blanchard OJ, Leigh D (2013) Growth forecast errors and fiscal multipliers. Am Econ Rev 103(3):117-120

Charles S (2016) An additional explanation for the variable Keynesian multiplier: the role of the propensity to import. J Post Keynes Econ 39(2):187-205

Charles S, Dallery T, Marie J (2015) Why the Keynesian multiplier increases during hard times: a theoretical explanation based on Rentiers' saving behaviour. Metroeconomica 66(3):451-473

Collignon S, Esposito P (2017) Measuring European competitiveness on the sectoral level. European Trade Union Institute, Brussels

De Cos PH, Moral-Benito E (2016) Fiscal multipliers in turbulent times: the case of Spain. Empir Econ 50(4):1589-1625

De Gregorio J, Giovannini A, Wolf HC (1994) International evidence on tradables and nontradables inflation. Eur Econ Rev 38(6):1225-1244

Gechert S, Hallett AH, Rannenberg A (2016) Fiscal multipliers in downturns and the effects of Euro Area consolidation. Appl Econ Lett 23(16):1138-1140

\footnotetext{
${ }^{14} \mathrm{http}$ //ec.europa.eu/eurostat/web/esa-supply-use-input-tables/data/workbooks. The same holds true for the estimations provided by Ntemiroglou (2016), which, in addition, are based on the levels of employees in each industry.
} 
Hein E, Schoder C (2011) Interest rates, distribution and capital accumulation-a post-Kaleckian perspective on the US and Germany. Int Rev Appl Econ 25(6):693-723

International Monetary Fund (2012) World economic outlook: coping with high debt and sluggish growth. International Monetary Fund, Washington

Kahn R (1931) The relation of home investment to unemployment. Econ J 41(162):173-198

Kurz HD (1985) Effective demand in a'classical'model of value and distribution: the multiplier in a Sraffian framework. Manch Sch 53(2):121-137

Kurz HD (2006) Goods and bads: sundry observations on joint production waste disposal and renewable and exhaustible resources. Prog Ind Ecol Int J 3(4):280-301

Kurz HD, Salvadori N (1995) Theory of production. A long-period analysis. Cambridge University Press, Cambridge Leriou E, Mariolis T, Soklis G (2016) An intersectoral analysis of the Greek economy: evidence from the symmetric inputoutput tables for the years 2005 and 2010. Bull Polit Econ 10(2):137-159

Malinvaud E (1959) Programmes d'expansion et taux d' intérêt. Econometrica 27(2):215-227

Mariolis T (2008) Pure joint production, income distribution, employment and the exchange rate. Metroeconomica 59(4):656-665

Mariolis T (2018a) A Sraffian (no) trade-off between autonomous demand and transfer payments. Metroeconomica 69(2):473-487

Mariolis T (2018b) The foreign-trade leakages in the Greek economy: evidence from the supply and use table for the year 2010. East West J Econ Bus 21(1-2):128-148

Mariolis T, Soklis G (2010) Additive labour values and prices: evidence from the supply and use tables of the French, German and Greek economies. Econ Issues 15(2):87-107

Mariolis T, Soklis G (2018) The static Sraffian multiplier for the Greek economy: evidence from the supply and use table for the year 2010. Rev Keynes Econ 6(1):114-147

Metcalfe JS, Steedman I (1981) Some long-run theory of employment, income distribution and the exchange rate. Manch Sch 49(1):1-20

Morishima M (1960) Economic expansion and the interest rate in generalized von Neumann models. Econometrica 28(2):352-363

Ntemiroglou N (2016) The Sraffian multiplier and the key-commodities for the Greek economy: evidence from the inputoutput tables for the period 2000-2010. Bull Polit Econ 10(1):1-24

Oelgemöller J (2013) Revealed comparative advantages in Greece, Ireland, Portugal and Spain. Intereconomics 48(4):243-253

Onaran Ö, Galanis G (2012) Is aggregate demand wage-led or profit-led? National and global effects. Conditions of Work and Employment Series No. 40, Geneva, International Labour Office

Piton S (2017) A European disease? Non-tradable inflation and real interest rate divergence. CESifo Econ Stud 63(2):210-234

Schefold B (1978) Multiple product techniques with properties of single product systems. J Econ 38(1):29-53

Sraffa P (1960) Production of commodities by means of commodities. Prelude to a critique of economic theory. Cambridge University Press, Cambridge

\section{Submit your manuscript to a SpringerOpen ${ }^{\odot}$ journal and benefit from:}

- Convenient online submission

- Rigorous peer review

- Open access: articles freely available online

- High visibility within the field

- Retaining the copyright to your article

Submit your next manuscript at $\boldsymbol{\nabla}$ springeropen.com 